\section{Natur og kultur vever livet sammen}

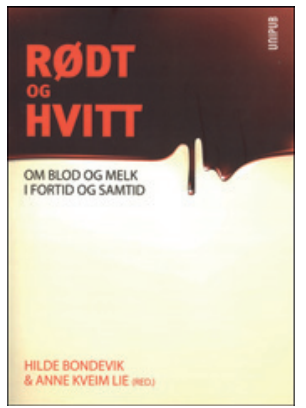

Hilde Bondevik, Anne Kveim Lie, red. Rødt og hvitt

Om blod og melk i fortid og samtid. 249 s, ill. Oslo: Unipub, 2012.

Pris NOK 298

ISBN 978-82-7477-519-0

Antologien er aktuell for alle som har interesse for kvinnehelse, både alminnelige lesere og fagfolk. Den er en akademisk artikkelsamling som omhandler melk, blod og kvinnekropp som natur, kultur og i et historisk perspektiv. Bidragsyterne er erfarne, velutdannede og skriveføre kvinner med bakgrunn innen historie, sosiologi, sosialantropologi og medisin.

Ikke overraskende er boken delt i to: rødt og hvitt. Redaktørene fokuserer i innledningen på kjønnsforskning, eller feministisk orientert forskning, som har hatt en viss avstand til «natur». Natur beskriver de som en «statisk størrelse, noe ubevegelig og konservativt som er resistent mot historisk, sosial og kulturell endring». De påpeker at den offentlige debatten om forskning har endret seg i løpet av det siste året. TV-serien Hjernevask på NRK i 2010 har bidratt til dette. Boken er en oppfordring til tverrfaglig dialog, der forskere innen humaniora og naturvitenskapelige fag viser hverandre gjensidig respekt og interesse. Ambisjonen er at de ulike bidragene skal overføre kunnskap mellom «de to kulturer». Leseren må avgjøre om den gjør så.

De ti artiklene er ulikt oppbygd og har forskjellig form og tidsperspektiv. Det er omskrevne, tidligere publiserte artikler og artikler basert på feltarbeid og studier i Afrika og Asia. Mye av stoffet er kjent, men det er også nye spennende betraktninger. Blod skaper følelser og er knyttet til symbolikk, frykt og redsel. Menstruasjonsblødninger er brukt mot kvinnen som en svakhet, og kvinner er blitt devaluert, kontrollert og ekskludert gjennom sine «ukontrollerte biologiske væsker». Bidragsyterne beskriver amming i et vitenskapelig, medisinsk, politisk og økonomisk perspektiv. Der morsmelk er den viktigste næringskilden, lever hivpositive afrikanske kvinner i et uløselig dilemma i spenningsfeltet mellom hensyn til det nyfødte barnets helse og sosial aksept, dvs. å unngå utstøting og stigmatisering.

Stoffet er oversiktlig disponert, og de ulike kapitlene er kort omtalt i innledningen. Tekstene er for det meste lettleste, men enkelte steder drukner budskapet $\mathrm{i}$ vanskelige formuleringer.

Menstruasjon og morsmelk er naturlige deler av kvinners liv, noe som alle må forholde seg til og mange (de fleste?) har et pragmatisk forhold til. En kliniker som daglig møter mennesker med problemstillinger knyttet til disse biologiske funksjonene, ser at det kan være besværlig, knyttet til plager og utfordringer og endog sykdom. Med dagens hjelpemidler er det ikke nødvendig å ha menstruasjon, og mange kvinner føler en lettelse over å slippe. Det pågår diskusjon om dette er naturlig kvinnelig.

Artikkelsamlingen er spennende og tankevekkende lesning. Den kan inspirere oss som mennesker og fagpersoner til å se livet som både natur og kultur - noe som vever livet sammen.

Kari Hilde Juvkam

Grimstad legesenter

\section{Inspirerende og praktisk om sosiale nettverk}

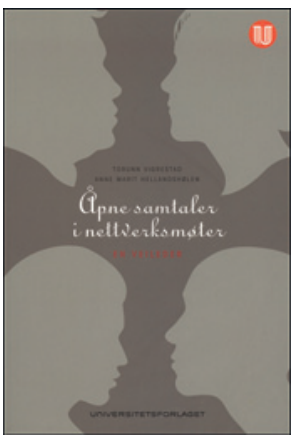

Torunn Vigrestad, Anne Marit Hellandshølen Åpne samtaler i nettverksmøter

En veileder. 241 s, ill. Oslo:

Universitetsforlaget, 2012. Pris NOK 299

ISBN 978-82-15-01400-5

Forfatterne er sykepleiere med bl.a. videreutdanning i psykisk helsearbeid og nettverksarbeid. De jobber begge ved Sykehuset Innlandet og har deltatt i, og fulgt utviklingen av, åpne samtaler i nettverksmøter gjennom flere år, både fra lederhold og praksis. De beskriver sin egen erfaring fra slike møter med personer med psykiske lidelser, og de kombinerer en praktisk tilnærming med historiske tilbakeblikk fra nettverksrelatert arbeid og teoretiske inspirasjonskilder.

Teksten er relevant og interessant både for studenter og fagpersoner i alle deler av helse- og sosialsektoren og for politikere og personer som har administrative oppgaver relatert til psykisk helsevern.

Boken er godt pedagogisk lagt opp. Vi får en detaljert forståelse av hva nettverksmøter er, og gjennomføring i praksis, ikke minst gjennom eksempler som bringer oss nær hva som kan foregå på slike møter. Det er noen få illustrasjoner som øker den praktiske tilgjengeligheten. Forfatterne lykkes med å gi boken en form som tilfredsstiller behov på ulike nivåer. De beskriver hvordan nettverksmøter kan igangsettes og gjennomføres, hva slags roller ulike aktører kan ha, hvem som kan ha nytte av det, og hva som kreves av de som skal lede slike møter. Henvisninger til litteratur gir nyttige tips for utdypende lesning.

Nettverksmøter er en krevende tilnærming som krever høy faglig kompetanse, personlige egenskaper og engasjement. Selv om det er kompliserte strukturer som skal forstås og håndteres, klarer forfatterne å formidle hvordan teori og praksis henger sammen. Det er ni kapitler. Kapittel 6, det største, handler om hvordan nettverksmøter kan gjennomføres. Det har en kokeboktilnærming som gir leseren et konkret bilde av hva som kan gjøres. De siste kapitlene gir perspektiver på hva denne tilnærmingen kan ha av helsepolitiske føringer på samhandling og samarbeid, forskning og utdanning knyttet til arbeid med nettverksmøter, og perspektiver på fremtiden.

For en som har arbeidet med sosiale nettverk og mental helse gjennom en lang forskerkarriere var dette en forfriskende bok. Det er spennende å se hvordan dediserte fagfolk utenfor de såkalte sentrene kan utvikle kunnskap og praksis som kan gi sentrale helsepolitiske føringer, og å se at de kan anvende teori i nærhet til den hverdag pasienter og behandlere deler. Det minner om hvilket høyt faglig nivå som trengs for å forholde seg til det alminnelige. For mange pasienter er det nettopp i det hverdagslige at lidelsen viser de viktigste og vanskeligste utfordringene. Boken kan og bør leses av et vidt spekter av fagfolk, forskere og også de som på overordnet helsefremmingsplan ønsker viten om hvordan man kan påvirke psykisk helse på ulike nivåer.

\section{Tom Sørensen}

Klinikk for psykisk helse og avhengighet Institutt for klinisk medisin

Universitetet i Oslo

Oppgitte interessekonflikter: Anmelder har foretatt undersøkelser i Valdres lokalsamfunn. Han har veiledet forsker (ingen av forfatterne) som har undersøkt pasienter i Valdres. 